\title{
Extracorporeal membrane oxygenation via sternotomy for circulatory shock
}

\author{
Stephen Horton, PhD, ${ }^{\mathrm{a}, \mathrm{c}}$ Yves d'Udekem, MD, ${ }^{\mathrm{a}, \mathrm{c}}$ Frank Shann, MD, ${ }^{\mathrm{b}}$ Warwick Butt, MBBS, \\ Martin Bennett, BAppSc, ${ }^{\mathrm{a}}$ Derek Best, RN, ${ }^{\mathrm{b}}$ and Christian Brizard, MD, ${ }^{\mathrm{a}, \mathrm{c}}$ Victoria and Melbourne, \\ Australia
}

Extracorporeal membrane oxygenation (ECMO) has been used to treat sepsis in children at the Royal Children's Hospital since 1988 , with overall survival of $47 \%$. Before 2000 , our pediatric population requiring mechanical support for sepsis was supported with ECMO with cannulae implanted peripherally in the right common carotid artery and the right internal jugular vein. Since 2000, to improve delivered flows, we started to cannulate directly the aorta and right atrium through a sternotomy.

\section{PATIENTS AND METHODS}

From 1988 to 2007, 47 pediatric patients had ECMO support for sepsis (Table 1) using our technique as previously described. ${ }^{1}$ Meningococcal septicemia was the single largest group $(\mathrm{n}=13)$. Indications for ECMO for septic shock were severe hypotension, evidence of inadequate end-organ perfusion (persistent metabolic acidosis, renal failure) despite adequate fluid resuscitation, and high-dose inotropic support (adrenaline $>1 \mu \mathrm{g} \cdot \mathrm{kg}^{-1}$. $\mathrm{min}^{-1}$ or the need for repeated bolus doses of adrenaline or external cardiac massage). ECMO was considered in patients with respiratory failure if ventilator target values $(\mathrm{pH}>7.25$, arterial oxygen saturation $>88 \%$ ) could not be achieved with mechanical ventilation with a fractional inspired oxygen concentration $\left(\mathrm{FiO}_{2}\right)$ less than 0.9 and high positive end expiratory pressure (PEEP), long inspiratory time, change in patient position, or high-frequency oscillatory ventilation. Patients were excluded from ECMO if they had received high-pressure mechanical ventilation with a peak inspiratory pressure $(\mathrm{PIP})>35 \mathrm{~cm} \mathrm{H}_{2} \mathrm{O}$, had an $\mathrm{FIO}_{2}>0.6$ for more than 10 to 14 days, or had underlying irreversible disease or evidence of a recent cerebral hemorrhage.

All patients required venoarterial ECMO using the highest flows (150 to $300 \mathrm{~mL} / \mathrm{kg} / \mathrm{min}$ ) achievable to maintain adequate peripheral perfusion. ECMO flow rates were adjusted to achieve maximal systemic perfusion at age-appropriate perfusion pressures, where cannula size permitted. Systemic perfusion was judged to be adequate if there was correction of metabolic acidosis, an arterial oxygen saturation of more than $90 \%$, and a mixed venous oxygen saturation of more than $65 \%$. If adequate perfusion was not achieved in patients who were cannulated peripherally with a right internal jugular ve-

From the Department of Cardiac Surgery, ${ }^{\text {a }}$ Royal Children's Hospital, Victoria, Australia; Intensive Care Unit, ${ }^{\mathrm{b}}$ Royal Children's Hospital, Victoria, Australia; and University of Melbourne, ${ }^{\mathrm{c}}$ Melbourne, Australia.

Disclosures: None.

Received for publication April 19, 2008; accepted for publication July 10, 2008; available ahead of print Sept 9, 2008.

Address for reprints: Stephen B. Horton, PhD, Royal Children's Hospital, Department of Cardiac Surgery, Flemington Road, Parkville, Victoria 3052, Australia (E-mail: steve.horton@rch.org.au).

J Thorac Cardiovasc Surg 2010;139:e12-3

0022-5223/\$36.00

Crown Copyright (C) 2010 Published by Elsevier Inc. on behalf of The American Association for Thoracic Surgery

doi:10.1016/j.jtcvs.2008.07.029 nous cannula, then a maximally sized left femoral venous cannula was also used. All patients received a continuous heparin infusion for anticoagulation, titrated to achieve an activated clotting time of 160 seconds (MAX-ACT, Helena laboratories, Beaumont, Tex), with platelet count maintained at more than $100,000 / \mu \mathrm{L}$. If chest drain blood loss was greater than $5 \mathrm{~mL}$. $\mathrm{kg}^{-1} \cdot \min ^{-1}$, then aprotinin was infused at $10,000 \mathrm{kIU} \cdot \mathrm{kg}^{-1} \cdot \mathrm{h}^{-1}$; In 5 patients, bleeding persisted despite surgical reexploration. Heparin was stopped and prostacyclin infused at $5 \mathrm{ng} \cdot \mathrm{kg}^{-1} \cdot \mathrm{min}^{-1}$.

Once adequate ECMO flow had been established, the ventilator settings were reduced ( $\mathrm{PIP}<25 \mathrm{~cm} \mathrm{H}_{2} \mathrm{O}$, PEEP $10 \mathrm{~cm} \mathrm{H}_{2} \mathrm{O}, 10$ breaths/minute, $\mathrm{FIO}_{2}$ 0.21 to 0.30 ) to minimize iatrogenic lung damage. When satisfactory systemic perfusion had been achieved on ECMO, inotrope infusions were reduced to optimize conditions for myocardial recovery. Continuous hemofiltration was undertaken where necessary for renal replacement therapy.

Wilcoxon rank-sum test was used to test whether there were any significant differences between the 2 groups (Table 1) or difference in outcome $(P=.02)$.

\section{RESULTS}

In group $1(\mathrm{n}=35)$, the cannulae were surgically inserted in the peripheral vessels (neck or groin) with 1 or more venous cannulae. In group $2(\mathrm{n}=12)$, a median sternotomy was performed, and the ECMO was instituted between the body of the right atrium and the ascending aorta. The maximal achievable mean ECMO flow averaged for the first 24 hours was $2.40 \mathrm{~L} \cdot \mathrm{min}^{-1} \cdot \mathrm{m}^{-2}$ in group 1 , and $3.43 \mathrm{~L}$. $\min ^{-1} \cdot \mathrm{m}^{-2}$ in group $2(P=.002)$. There were 22 deaths in group $1(63 \%)$ and 3 deaths in group $2(25 \% ; P=$ $0.02)$. Transthoracic cannulation has been described to increase the risk of bleeding ( $31.4 \mathrm{vs} 0.9 \mathrm{~mL} / \mathrm{kg}$ ) as well as the incidence of nosocomial infection $(36 \% \mathrm{vs} 19 \%)^{2}$; however, we found no difference with blood requirements between the 2 groups (Table 1) or the rate of nosocomial infection (37\% vs 33\%).

The 2005 Pediatric Sepsis Consensus criteria were used to define septic shock and organ dysfunction, ${ }^{3}$ and on admission to the intensive care unit, all patients were receiving antibiotics and had positive bacterial cultures (except for a single patient with positive viral immunofluorescence from a lower respiratory tract sample).

\section{DISCUSSION}

Sepsis is common in patients in intensive care in Australia; as well as increasing morbidity, it is an important cause of mortality and has become the second commonest cause of death in preterm infants. In our retrospective report encompassing the last 20 years, septic shock necessitating ECMO constituted $10 \%$ of extracorporeal life support (ECLS). 
TABLE 1. Median patient variables immediately prior to ECMO and blood product use during ECMO

\begin{tabular}{|c|c|c|c|}
\hline & $\begin{array}{c}\text { Carotid artery/jugular vein } \\
\text { cutdown median } \\
\text { (interquartile } \\
\text { range), group } 1\end{array}$ & $\begin{array}{l}\text { Sternotomy, median } \\
\text { (interquartile range), } \\
\text { group } 2\end{array}$ & $\begin{array}{c}P \\
\text { value }\end{array}$ \\
\hline Age (mo) & $17(1.5-90)$ & $47.5(6.3-153.2)$ & .17 \\
\hline Surface area $\left(\mathrm{m}^{2}\right)$ & $0.46(0.23-0.86)$ & $0.85(0.31-1.38)$ & .16 \\
\hline Sex $(\%$ males $)$ & 63 & 67 & \\
\hline Hours ICU pre-ECMO & $21.7(3.9-28.3)$ & $10.3(6.2-38.6)$ & .73 \\
\hline Average flow $\mathrm{L} / \mathrm{m}^{2}$ first $24 \mathrm{~h}$ & $2.40(2.39-2.73)$ & $3.43(2.93-4.57)$ & .002 \\
\hline Hours on ECMO & $99(38-165)$ & $87(23-119)$ & .07 \\
\hline Blood pressure $(\mathrm{mm} \mathrm{Hg})$ & $48(38-70)$ & $53(38-62)$ & .96 \\
\hline $\mathrm{pH}$ prior to ECMO & $7.25(7.15-7.33)$ & $7.11(7.03-7.29)$ & .04 \\
\hline Packed red cells $\left(\mathrm{mL} \cdot \mathrm{kg}^{-1} \cdot \mathrm{h}^{-1}\right)$ & $1.0(0.5-2.3)$ & $1.3(0.6-4.3)$ & .48 \\
\hline Platelets $\left(\mathrm{mL} \cdot \mathrm{kg}^{-1} \cdot \mathrm{h}^{-1}\right)$ & $0.56(0.26-1.57)$ & $0.6(0.3-1.3)$ & .94 \\
\hline Fresh frozen plasma $\left(\mathrm{mL} \cdot \mathrm{kg}^{-1} \cdot \mathrm{h}^{-1}\right)$ & $0.62(0.06-1.43)$ & $1.2(0.2-2.2)$ & .15 \\
\hline
\end{tabular}

$E C M O$, Extracorporeal membrane oxygenation; $I C U$, intensive care unit.

TABLE 2. Median patient biochemistry results of the 2 groups (sternotomy/carotid artery-jugular vein cutdown) immediately prior to and 24 and 156 hours after ECMO institution

\begin{tabular}{ccccc}
\hline & $\mathbf{H b}(\mathbf{g} / \mathbf{L})$ & Lactate $(\mathbf{m m o l} / \mathbf{L})$ & Creatinine $(\mathbf{m m o l} / \mathbf{L})$ & Albumin $(\mathbf{g} / \mathbf{L})$ \\
\hline Pre & $100 / 120$ & $6.0 / 8.2$ & $0.11 / 0.09$ & .09 \\
$P$ value & .40 & .32 & .39 & .05 \\
$24 \mathrm{~h}$ & $94.5 / 119$ & $3.1 / 5.8$ & $0.11 / 0.09$ & $28 / 35$ \\
$P$ value & .03 & .03 & .30 & .07 \\
$156 \mathrm{~h}$ & $116.5 / 118$ & $1.0 / 1.7$ & $0.07 / 0.10$ & $30 / 34$ \\
$P$ value & .69 & .001 & .96 & .20 \\
\hline
\end{tabular}

ECMO, Extracorporeal membrane oxygenation.

Eighteen patients prior to institution of venoarterial ECMO were receiving chest compressions as they were in cardiac arrest, with 41 patients having failure of at least 3 organ systems and 28 requiring hemofiltration (reducing incidence of edema in either group). Randomized controlled trails for ECMO have been undertaken by others ${ }^{4}$; however, studies utilizing different cannulation sites for septic shock are unlikely to be performed due to the poor outcome in the peripheral cannulation group, which necessitated that we use a novel alternative. The institution of ECMO via transthoracic cannulation allowed us to achieve adequate metabolic support using larger cannulae than with percutaneous cannulation of the jugular or femoral veins, with flows of $3.43 \mathrm{~L} \cdot \mathrm{min}^{-1} \cdot \mathrm{m}^{-2}$ versus $2.40 \mathrm{~L} \cdot \mathrm{min}^{-1} \cdot \mathrm{m}^{-2}(P=0.002)$. The introduction of new technology ${ }^{1}$ allowed us to make use of high-flow ECMO, which even with cannulation via sternotomy would not have been able to achieve these flows as our previous ECMO circuit was a high resistance system. ${ }^{5}$ Also, Traysylol, which has been used in both groups but to a greater extent in the sternotomy group, may have been a contributing factor in there being no difference in blood product transfusion. With this product having probable future limited availability, we are currently researching novel anticoagulation regimens utilizing low-dose heparin (10 IU $\cdot \mathrm{kg}^{-1} \cdot \mathrm{h}^{-1}$ ) in conjunction with platelet suppression (prostacyclin $5 \mathrm{ng} \cdot \mathrm{kg}^{-1} \cdot \mathrm{h}^{-1}$ and nitric oxide $5 \mathrm{ppm}$ into the ventilating gas of the oxygenator). Elevations of markers of end-organ function (lactate, creatinine, liver enzymes) before and soon after starting ECMO are associated with increased mortality; early, marked elevations identify those children likely to require support, as well as reflect the effectiveness of resuscitative efforts. We have found that high-flow ECMO via central access sternotomy optimizes end-organ perfusion as evidenced by a significantly lower lactate at 24 and 156 hours (Table 2) with a significant improvement in survival.

\section{References}

1. Horton S, Thuys C, Bennett M, Augustin S, Rosenberg M, Brizard C. Experience with the Jostra Rotaflow and Quadrox ${ }_{D}$ oxygenator for ECMO. Perfusion. 2004; 19:17-23.

2. O’Neill JM, Schutze GE, Heulitt MJ, Simpson PM, Taylor BJ. Nosocomial infections during extracorporeal membrane oxygenation. Intensive Care Med. 2001;27: 1247-53.

3. Goldstein B, Giroir B, Randolph A. International pediatric sepsis consensus conference: definitions for sepsis and organ dysfunction in pediatrics. Pediatr Crit Care Med. 2005;6:2-8.

4. UK Collaborative ECMO Trial Group. UK collaborative randomised trial of neonatal extracorporeal membrane oxygenation. Lancet. 1996;348:75-82.

5. Horton SB, Horton AM, Mullaly RJ, Butt WW, Mee RBB. Extracorporeal membrane oxygenation life support: a new approach. Perfusion. 1993;8:239-47. 